\title{
Transcription factor 21 gene polymorphism in patients with coronary artery disease
}

\author{
Waleed Abdou Hamed' \\ Ghada E Hammouda ${ }^{2}$ \\ Sally M El-Hefnawy ${ }^{2}$ \\ Eman M Abd El-Gayed ${ }^{2}$ \\ 'Cardiology Department, \\ 2Biochemistry Department, Faculty of \\ Medicine, Menoufia University, Shebin \\ El-Kom, Egypt
}

This article was published in the following Dove Press journal:

Research Reports in Clinical Cardiology

14 February 2017

Number of times this article has been viewed

Background: $\mathrm{CAD}$ is the most common type of heart disease and the leading cause of death in both men and women. Transcription factor 21 (TCF21) is required for normal epicardial development and regulates epicardium-derived cell (EPDC) differentiation into smooth muscle and fibroblast lineages. Objectives: The aim of this study was to investigate the distribution of TCF21 (12190287G/C) gene polymorphism in patients with $\mathrm{CAD}$ and its association with other clinical and laboratory variables in these patients.

Patients and methods: This study was carried out in 100 patients with CAD, and 50 healthy subjects served as controls. All studied subjects underwent laboratory investigations, including measurement of total cholesterol (TC), triglycerides (TG), low-density lipoprotein cholesterol (LDL-c), high-density lipoprotein cholesterol (HDL-c), creatinine kinase-MB (CK-MB), troponin I (TnI) and genotyping of TCF21 (12190287G/C) gene using the TaqMan Allelic Discrimination assay technique. Results: Serum creatinine, TC, TG, LDL-c, CK-MB and TnI were significantly higher in patients with $\mathrm{CAD}$ than in the control group. There was a statistically significant difference regarding genotype frequency of TCF 21 (12190287G/C) polymorphism between the two studied groups, with the highest frequency of GG genotype among the control group, while CC genotype had the highest frequency in the patient group. C allele was more frequent in the patient group, while $\mathrm{G}$ allele was more frequent in the control group.

Conclusion: CC genotype and C allele of TCF21 (12190287G/C) polymorphism are considered as genetic risk factors for CAD; these findings could have an impact on the future preventive and management protocols in this group of patients.

Keywords: coronary artery disease, transcription factor, gene polymorphism

\section{Introduction}

Coronary artery disease (CAD) is a multifactorial disease and considered the main cause of death in many countries. ${ }^{1}$ Many risk factors contribute to the pathogenesis of CAD, such as smoking, diabetes, hypertension, hypercholesterolemia, obesity, physical inactivity and stress. ${ }^{2}$ Although many patients with CAD share similar risk factors, it is not clear why some individuals are more susceptible to these environmental determinants than others with the same risk factors, pointing to a complex interaction of both environmental and genetic factors. ${ }^{3}$

Recently, genome-wide association studies (GWASs) have identified several common variants that are associated with the risk of CAD and myocardial infarction. ${ }^{4}$

Transcription factor 21 (TCF21) is a class II basic helix-loop-helix transcription factor that is produced in the mesenchyme of developing organs such as the lung, kidney and epicardium. ${ }^{5}$ 
In the heart, $T C F 21$ is required for normal epicardial growth and regulates epicardium-derived cell (EPDC) differentiation into smooth muscle cells and fibroblast cells. Vascular smooth muscle cells and cardiac fibroblasts are essential for the development of the coronary vasculature and cardiac fibrous matrix, which support myocardial integrity and function in the heart. ${ }^{6}$

TCF21 attaches certain DNA sequences and regulates cell differentiation by regulating cell cycle arrest and tissue gene expression. ${ }^{7}$

The rs 12190287 is present in the exon of the TCF21 and is considered an expression quantitative trait locus for this gene by regulating TCF 21 gene expression. ${ }^{8}$ The gene study indicated that the $\mathrm{C}$ allele of rs12190287 enhanced the expression of TCF21 in vascular smooth muscle cells. ${ }^{9}$

\section{Aim of the study}

The aim of the present study was to investigate the distribution of TCF21 (12190287G/C) gene polymorphism in patients with $\mathrm{CAD}$ and its association with other clinical and laboratory variables in these patients.

\section{Patients and methods}

The present study was carried out in 100 patients with CAD (56 males and 44 females) with a mean age of $52.3 \pm 4.1$ years; the diagnosis of $\mathrm{CAD}$ was based on coronary angiographic demonstration of $>50 \%$ stenosis in at least one of the major epicardial coronary arteries. The patients were selected from the Cardiology Department, Menoufia University, in the period from April 2015 to October 2015.

This patient group was compared with 50 (32 males and 18 females) age-matched and sex-matched healthy subjects with a mean age of $51.2 \pm 3.4$ years who had no detectable cardiovascular risk factors and did not receive any medications. Control subjects were volunteers from the hospital staff, medical and nursing students and members of the local community. The studied population was enrolled after obtaining the written informed consent and after approval from the university research ethics committee of Menoufia University Hospitals.

Patients with valvular heart disease, heart failure or hepatic or renal dysfunction were excluded from this study.

All patients and control groups were subjected to complete history taking, complete clinical examination, electrocardiography (ECG) and laboratory investigation, including fasting blood sugar (FBS), lipid profile, urea, creatinine, creatinine kinase-MB (CK-MB), troponin I (TnI) and genotyping of TCF21 (rs12190287).

\section{Sample collection and assay}

A total of $10 \mu \mathrm{L}$ of venous blood was obtained from all subjects as follows: $2 \mu \mathrm{L}$ into tubes containing EDTA for genotyping of TCF 21 gene and $8 \mu \mathrm{L}$ into tubes without additives for separation of serum for colorimetric measurement of urea,${ }^{10}$ creatinine, ${ }^{11}$ total creatine kinase (CK) and CK-MB levels, ${ }^{12}$ total cholesterol (TC), ${ }^{13}$ triglycerides $(\mathrm{TG})^{14}$ and high-density lipoprotein cholesterol (HDL-c).${ }^{15}$ Low-density lipoprotein cholesterol (LDL-c) was calculated according to the Friedewald equation. ${ }^{16}$ Enzyme-linked immunosorbent assay (ELISA) was done for the measurement of serum TnI. ${ }^{17}$

\section{TCF2 I genotyping}

DNA was extracted from whole blood using GeneJET Whole Blood Genomic DNA Purification Mini Kit (Thermo Fisher Scientific, Waltham, MA, USA).

TCF21 gene was genotyped using the TaqMan allelic Discrimination method, which determines variants of single nucleic acid sequence. Using two primer/probe pairs in each reaction allows genotyping of the two possible variants at the single nucleotide polymorphism in a target template sequence.

Using the maxima probe qPCR Master Mix (2X), primers and probes were applied from Thermo Fisher Scientific; the forward primer was 5'-CTCCAAGGGCTGAGAACTTCGGTGA-3' and the reverse primer was 5'-TTCATCCACCTGTCTATTTGCACAT-3'.

The genotyping reaction was done by adding $10 \mu \mathrm{L}$ of master mix, $1.25 \mu \mathrm{L}$ of the genotyping ready-made assay mix (probes and primers) and $3.75 \mu \mathrm{L}$ of DNAase-free water. For every unknown reaction, $5 \mu \mathrm{L}$ of genomic DNA template and $5 \mu \mathrm{L}$ of DNAase-free water for the negative control reaction were applied.

The cycling parameters were as follows: first, denaturation was done at $95^{\circ} \mathrm{C}$ for 10 minutes, followed by 40 cycles of denaturation at $94^{\circ} \mathrm{C}$ for 15 seconds, annealing at $50^{\circ} \mathrm{C}$ for 60 seconds and then extension at $72^{\circ} \mathrm{C}$ for 2 minutes and the last extension at $72^{\circ} \mathrm{C}$ for 1 minute. Data analysis was performed using 7500 Real-Time PCR System, software version 2.0.1.

\section{Statistical analysis}

Results were collected, tabulated and statistically analyzed by IBM personal computer and statistical package SPSS version 20 (IBM Corporation, Armonk, NY, USA). Chi-square test $\left(\chi^{2}\right)$ was used to study the association between two qualitative variables. Odds ratio (OR) describes the probability that people who are exposed to a certain factor will have a 
disease compared to people who are not exposed to the factor. Student's $t$-test was used for comparison between two groups having quantitative variables. Analysis of variance (ANOVA) $(F)$ test was used for comparison between three or more groups having quantitative variables. Multiple regression analysis was performed to calculate the effects of risk factors as independent ORs with the effects of other confounders removed. $P$-value $<0.05$ was statistically significant.

\section{Results}

The clinical, echocardiographic and baseline characteristics of the study population are depicted in Table 1 . There was a statistically significant difference between the two studied groups regarding heart rate, systolic blood pressure ejection fraction and smoking $(P<0.05)$, while there was no significant difference as regards other clinical data, medical history, age and sex.

Furthermore, there was a statistically significant difference between the two studied groups regarding creatinine, TC, TG, LDL-c, HDL-c, CK-MB, TnI $(P<0.05)$ and FBS $(P<0.001)$, while there was no significant difference regarding blood urea (Table 2).

Interestingly, TCF21 genotype distribution between the two studied groups showed a significant difference, with increased frequency of the $\mathrm{CC}$ and $\mathrm{GC}$ genotypes and $\mathrm{C}$ allele in the patient group and increased GG genotype frequency in the control group $(P<0.05$; Table 3 and Figure 1).

The results also showed that the GC genotype of TCF21 increases the risk of CAD by 2.3 -fold and CC genotype increases the risk by 5.9 -fold, while the $\mathrm{C}$ allele increases the same risk by 2.9-fold, as shown in Table 3 .

There was also a statistically significant difference among different genotypes of $T C F 21$ in patients with CAD

Table I Demographic characteristics and clinical data of the studied groups

\begin{tabular}{|c|c|c|c|}
\hline Parameter & $\begin{array}{l}\text { Control } \\
(n=50)\end{array}$ & $\begin{array}{l}\text { Patients } \\
(n=100)\end{array}$ & $P$-value \\
\hline Age (years), mean $\pm S D$ & $51.2 \pm 3.4$ & $52.3 \pm 4.1$ & $>0.05$ \\
\hline \multicolumn{4}{|l|}{ Sex, n (\%) } \\
\hline Male & $32(64)$ & $56(56)$ & $>0.05$ \\
\hline Female & $18(36)$ & $44(44)$ & \\
\hline $\mathrm{HR}$ (beat $/ \mathrm{min})$, mean $\pm \mathrm{SD}$ & $73.5 \pm 5.3$ & $88.6 \pm 4.6$ & $<0.05$ \\
\hline $\begin{array}{l}\text { Systolic blood pressure }(\mathrm{mmHg}) \\
\text { mean } \pm \mathrm{SD}\end{array}$ & $125.2 \pm 3.1$ & $160.1 \pm 6.8$ & $<0.05$ \\
\hline $\begin{array}{l}\text { Diastolic blood pressure } \\
(\mathrm{mmHg}), \text { mean } \pm \mathrm{SD}\end{array}$ & $80.7 \pm 7.8$ & $81.2 \pm 3.6$ & $>0.05$ \\
\hline $\mathrm{EF}(\%)$, mean $\pm \mathrm{SD}$ & $60.6 \pm 4.3$ & $50.4 \pm 3.2$ & $<0.05$ \\
\hline \multicolumn{4}{|l|}{ Smoking, n (\%) } \\
\hline$+\mathrm{ve}$ & $16(32)$ & $62(62)$ & $<0.05$ \\
\hline$-\mathrm{ve}$ & $34(68)$ & $38(38)$ & \\
\hline
\end{tabular}

Abbreviations: $E F$, ejection fraction; $H R$, heart rate; SD, standard deviation. regarding the lipid profile and $\mathrm{TnI}$; patients with $\mathrm{CC}$ genotype predominance showed higher levels of TC, TG, LDL-c and TnI $(P<0.05)$, while HDL-c was significantly higher in patients with a predominance of GG genotype, as shown in Table 4.

Using multivariate analysis for predicting risk factors for CAD, the most significant risk factors were CC genotype (OR 44.7, $P<0.001$ ), smoking (OR 22.1, $P<0.001$ ) and FBS (OR 15.4, $P<0.001$ ), followed by LDL-c (OR 13.1, $P<0.05)$, TG (OR 9.9, $P<0.05)$ and TC (OR 7.1, $P<0.05)$ as shown in Table 5.

\section{Discussion}

CAD is an important cause of death and disability in both developed and developing countries. ${ }^{18,19} \mathrm{CAD}$ is a complex disease caused by the inheritance of multiple genetic variants together with environmental factors promoting the disease state. ${ }^{20}$ Genome-wide associations (GWAs) have explored several genetic variant associations with $\mathrm{CAD} .^{21,22}$

Table 2 Comparison between the studied groups regarding laboratory parameters

\begin{tabular}{llll}
\hline Parameter & $\begin{array}{l}\text { Control } \\
(\mathbf{n}=\mathbf{5 0}) \\
(\mathbf{m e a n} \pm \mathbf{S D})\end{array}$ & $\begin{array}{l}\text { Patients } \\
(\mathbf{n}=\mathbf{1 0 0}) \\
(\mathbf{m e a n} \pm \mathbf{S D})\end{array}$ & P-value \\
\hline $\begin{array}{l}\text { Serum creatinine }(\mathrm{mg} / \mathrm{dL}) \\
\text { Blood urea }\end{array}$ & $0.98 \pm 0.3$ & $1.66 \pm 0.4$ & $<0.05$ \\
$(\mathrm{mg} / \mathrm{dL})$ & $28.6 \pm 4.6$ & $30.4 \pm 5.2$ & $>0.05$ \\
TC $(\mathrm{mg} / \mathrm{dL})$ & $152.4 \pm 23.6$ & $172.3 \pm 22.4$ & $<0.05$ \\
TG $(\mathrm{mg} / \mathrm{dL})$ & $105.1 \pm 19.6$ & $130.5 \pm 20.2$ & $<0.05$ \\
LDL-c $(\mathrm{mg} / \mathrm{dL})$ & $84.5 \pm 13.2$ & $105.2 \pm 16.7$ & $<0.05$ \\
HDL-c $(\mathrm{mg} / \mathrm{dL})$ & $47.6 \pm 10.1$ & $37.4 \pm 9.5$ & $<0.05$ \\
CK-MB $(\mathrm{IU} / \mu \mathrm{L})$ & $15.2 \pm 5.6$ & $35.5 \pm 8.9$ & $<0.05$ \\
Tnl $(\mu \mathrm{g} / \mathrm{L})$ & $0.18 \pm 0.1$ & $0.62 \pm 0.2$ & $<0.05$ \\
FBS $(\mathrm{mg} / \mathrm{dL})$ & $106.5 \pm 18.7$ & $201.3 \pm 64.2$ & $<0.001$ \\
\hline
\end{tabular}

Abbreviations: CK-MB, creatine kinase-MB; FBS, fasting blood sugar; HDL-c, highdensity lipoprotein cholesterol; LDL-c, low-density lipoprotein cholesterol; SD, standard deviation; TC, total cholesterol; TG, triglycerides; Tnl, troponin I.

Table 3 Comparison of TCF2I genotypes between the studied groups

\begin{tabular}{|c|c|c|c|c|c|c|c|}
\hline \multirow[t]{2}{*}{ Genotypes } & \multicolumn{2}{|c|}{$\begin{array}{l}\text { Control } \\
(n=50)\end{array}$} & \multicolumn{2}{|c|}{$\begin{array}{l}\text { Patients } \\
(\mathrm{n}=100)\end{array}$} & \multirow[t]{2}{*}{$\chi^{2}$} & \multirow[t]{2}{*}{$P$-value } & \multirow[t]{2}{*}{ OR $(95 \% \mathrm{Cl})$} \\
\hline & $\mathbf{n}$ & $\%$ & $\mathbf{n}$ & $\%$ & & & \\
\hline \multicolumn{8}{|c|}{ TCF2 I genotype } \\
\hline GG & 22 & 44 & 14 & 14 & 8.4 & $<0.05$ & - \\
\hline GC & 20 & 40 & 56 & 56 & & & $2.3(0.7-8.1)$ \\
\hline $\mathrm{CC}$ & 8 & 16 & 30 & 30 & & & $5.9(1.4-25.2)$ \\
\hline \multicolumn{8}{|l|}{ Allele } \\
\hline $\mathrm{G}$ & 64 & 64 & 84 & 42 & 9.2 & $<0.05$ & - \\
\hline $\mathrm{C}$ & 36 & 36 & 116 & 58 & & & $2.9(1.4-5.8)$ \\
\hline
\end{tabular}

Abbreviations: $\mathrm{Cl}$, confidence interval; OR, odds ratio; TCF2 I, transcription factor 21 . 

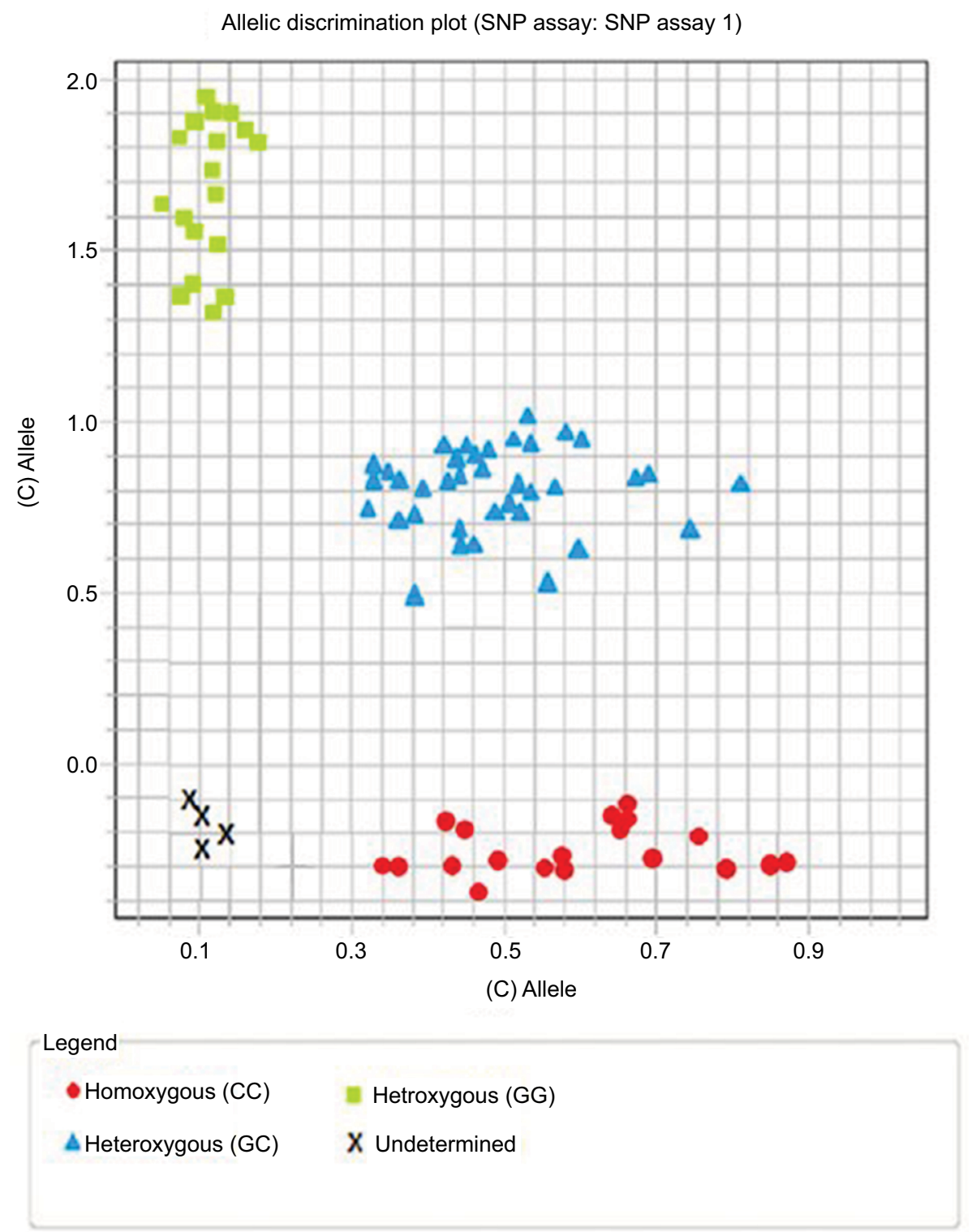

Figure I Allelic discrimination plot showing CC, GC and GG genotypes. Abbreviation: SNP, single nucleotide polymorphism.

In the heart, TCF21 is required for normal epicardial development and controls EPDC differentiation into smooth muscle and fibroblast cell lines. ${ }^{6}$

The present study revealed that smoking is a strong risk factor for CAD, which is consistent with many studies. ${ }^{23-26}$ Smoking is associated with excess oxidative stress, free radicals and release of cytokines. ${ }^{26}$

Furthermore, this study showed that systolic blood pressure was significantly higher in patients with CAD as compared to the control group; these results are in agreement with Cannon ${ }^{27}$ who found that hypertensive patients have more risk of CAD in relation to patients with normal blood pressure. McCann et $\mathrm{al}^{23}$ showed that systolic blood pressure was higher in patients with CAD compared to controls. Surprisingly, we revealed no significant difference in diastolic blood pressure between patients and controls in contrast to that reported by Santos et a ${ }^{28}$ who indicated high diastolic blood pressure in patients with CAD when compared to the control group. The explanation of our results may be because most of the hypertensive individuals in the patient group were suffering from only systolic hypertension.

The current study showed that serum creatinine was higher in patients with CAD compared to the control group. These results agree with those of Santos et al. ${ }^{28}$

Inrig et $\mathrm{al}^{29}$ reported that $\sim 40 \%$ of patients who present with CAD have some degree of renal impairment.

Furthermore, our study showed that serum TC and serum TG were increased in patients with CAD. These results run in 
Table 4 Biochemical parameters of the studied patients with CAD in different genotypes of TCF2I

\begin{tabular}{|c|c|c|c|c|}
\hline Paran & $\begin{array}{l}\text { GG }(n=14) \\
(\text { mean } \pm S D)\end{array}$ & $\begin{array}{l}\mathrm{GC}(\mathrm{n}=56) \\
(\mathrm{mean} \pm \mathrm{SD})\end{array}$ & $\begin{array}{l}C C(n=30) \\
(\text { mean } \pm S D)\end{array}$ & $P$-value \\
\hline Urea (mg/dL) & $34 \pm 12.6$ & $32 \pm 18.7$ & $37 \pm 10.3$ & $>0.05$ \\
\hline $\begin{array}{l}\text { Creatinine } \\
(\mathrm{mg} / \mathrm{dL})\end{array}$ & $0.88 \pm 0.22$ & $0.99 \pm 0.20$ & $\mathrm{I} \pm 0.30$ & $>0.05$ \\
\hline $\mathrm{TC}(\mathrm{mg} / \mathrm{dL})$ & $132.5 \pm 22.8$ & $172.4 \pm 27.9$ & $202.8 \pm 35.1$ & $<0.05$ \\
\hline TG (mg/dL) & $|20.6 \pm| 4.5$ & $134.7 \pm 17.2$ & $139.6 \pm 18.1$ & $<0.05$ \\
\hline LDL-c (mg/dL) & $99.4 \pm 24.1$ & $103.6 \pm 28.5$ & $139.4 \pm 37.2$ & $<0.05$ \\
\hline HDL-c (mg/dL) & $43 \pm 3.3$ & $38.8 \pm 4$ & $35.4 \pm 5.4$ & $<0.05$ \\
\hline CK-MB (IU/ $/ \mu \mathrm{L})$ & $28.9 \pm 8.2$ & $35.3 \pm 14.9$ & $45.2 \pm 17.1$ & $<0.05$ \\
\hline $\operatorname{Tnl}(\mu \mathrm{g} / \mathrm{L})$ & $0.29 \pm 0.11$ & $0.37 \pm 0.30$ & $0.59 \pm 0.30$ & $<0.05$ \\
\hline
\end{tabular}

Abbreviations: $C A D$, coronary artery disease; $C K-M B$, creatine kinase-MB; $H D L-c$, high-density lipoprotein cholesterol; LDL-c, low-density lipoprotein cholesterol; SD, standard deviation; TC, total cholesterol; TG, triglycerides; Tnl, troponin I.

Table 5 Multivariate analysis of predicting risk factors in CAD

\begin{tabular}{lll}
\hline Risk factor & OR $(\mathrm{Cl})$ & P-value \\
\hline CC genotype & $44.7(14.9-4 \mid 3.7)$ & $<0.00 I$ \\
Smoking & $22.1(9.9-188.2)$ & $<0.00 I$ \\
FBS $(\mathrm{mg} / \mathrm{dL})$ & $15.4(8.6-121.7)$ & $<0.00 \mathrm{I}$ \\
LDL-c $(\mathrm{mg} / \mathrm{dL})$ & $13.1(1.5-112.9)$ & $<0.05$ \\
TG $(\mathrm{mg} / \mathrm{dL})$ & $9.9(1.2-99.8)$ & $<0.05$ \\
TC $(\mathrm{mg} / \mathrm{dL})$ & $7.1(1.18-32.9)$ & $<0.05$ \\
\hline
\end{tabular}

Abbreviations: $\mathrm{CAD}$, coronary artery disease; $\mathrm{Cl}$, confidence interval; $\mathrm{FBS}$, fasting blood sugar; LDL-c, low-density lipoprotein cholesterol; OR, odds ratio; TC, total cholesterol; TG, triglycerides.

parallel with McCann et $\mathrm{al}^{23}$ who reported that disturbance of lipoprotein metabolism with high-fat diets, obesity and physical inactivity have led to atherosclerotic disease in the developed countries. The common genetic disorders of lipoproteins with adverse environmental factors cause premature atherosclerosis.

Type 2 diabetes is linked with atherogenic dyslipidemia. It was found that the incidence of atherosclerosis is increased in diabetic patients compared to the general population. ${ }^{30,31}$ Subjects with diabetes mellitus have other risk factors such as obesity and hypertension; these risk factors appear to act in synchrony to increase plaque formation..$^{32}$ Oxidative stress due to hyperglycemia may explain association between diabetes and $\mathrm{CAD}$, as it leads to endothelial dysfunction and atherogenesis. ${ }^{33}$

This study showed that the mean concentration of CK-MB and $\mathrm{TnI}$ in the CAD group was significantly higher than that in the control group. Similar results were reported by Pasaoglu et a ${ }^{34}$ though $\mathrm{TnI}$ is more sensitive for minor degrees of myocardial injury. ${ }^{34-36}$

This study revealed that single nucleotide polymorphism (SNP) rs12190287 was significantly associated with CAD and the frequencies of $\mathrm{CC}$ and $\mathrm{GC}$ genotypes are associated with 5.9 and 2.3, respectively, higher risk of CAD than GG genotypes. Furthermore, $\mathrm{C}$ allele was associated with 2.9 higher risk of $\mathrm{CAD}$ than $\mathrm{G}$ allele. In agreement with our results, Schunkert et $\mathrm{al}^{21}$ and Wang et $\mathrm{al}^{37}$ reported a significant association of SNP rs12190287 of TCF21 with CAD. In contrast to our results, Chang et al ${ }^{38}$ did not find any association between rs 12190287 and CAD.

This difference in results of previous studies indicates that TCF21 may have different disease determinants in CAD development, and association between TCF 21 and CAD susceptibility may have an impact on patients' risk levels.

\section{Study limitations}

First, the maintenance medications for the patients were not standardized before randomization; they were on different types and doses of statin therapy, antiplatelet drugs and beta blockers; such a therapy may have a potential effect on the clinical and laboratory variables. Second, there was a lack of assessment of microRNAs (miRNAs), which are known to be involved in post-transcriptional regulation of gene expression and may affect both the stability and translation of mRNAs. Third, the study lacked a large validation population. Further prospective studies are thus needed to confirm our results.

\section{Conclusion}

CC genotype and C allele of TCF21 (12190287G/C) polymorphism are genetic risk factors for $\mathrm{CAD}$; this association could provide a new method to identify patients at higher cardiovascular risk.

\section{Disclosure}

The authors report no conflicts of interest in this work.

\section{References}

1. Karahan Z, Ugurlu M, Ucaman B, et al. Relation between apolipoprotein E gene polymorphism and severity of coronary artery disease in acute myocardial infarction. Cardiol Res Pract. 2015;2015:363458.

2. Anand S, Islam S, Rosengren A, et al. Risk factor for myocardial infarction in women and men. Insights from INTERHEART study. Eur Heart J. 2008;29:932-940.

3. Schunkert H, Exdmann J, Samani N. Genetics of myocardial infarction: a progress report. Eur Heart J. 2010;31(8):918-925.

4. Mehta N. Large-scale association analysis identifies 13 new susceptibility loci for coronary artery disease. Nat Genet. 2011;43:333-338.

5. Funato N, Ohyama K, Kuroda T, Nakamura M. Basic helix loophelix transcription factor epicardian/capsuling/pod-1 suppresses differentiation by negative regulation of transcription. J Biol Chem. 2003;278:7486-7493.

6. Braitsch C, Combs M, Quaggin S, Yutzey K. Pod/Tcf21 is regulated by retinoic acid signaling and inhibits differentiation of epicardium derived cells into smooth muscle in the developing heart. Dev. Biol; 368: 345-357): transcriptional control of cell lineage development in epicardium derived cells. J Dev Biol. 2012;1:91-111.

7. Smith L, Lin M, Brena R, et al. Epigenetic regulation of the tumor suppressor gene TCF21 on 6q23-q24 in lung and head and neck cancer. Proc Natl Acad Sci USA. 2006;103:982-987.

8. Miller C, Hass U, Diaz R, et al. Coronary heart disease-associated variation in TCF21 disrupts a mir-224 binding site and miRNA mediated regulation. PLoS Genet. 2014;10(3):e1004263. 
9. Miller C, Anderson D, Kundu R, et al. Disease-related growth factor and embryonic signaling pathway modulate an enhancer of TCF21 expression at the $6 \mathrm{q} 23.2$ coronary heart disease locus. PLoS Genet. 2013;9(7):el003652.

10. Tobacco A, Meiatini F, Moda E. Simplified enzymic/colorimetric serum urea nitrogen determination. Clin Chem. 1979;25:336-337.

11. Bowers D, Wong T, Kinetic A. Serum creatinine assay. A critical evaluation and review. Clin Chem. 1980;26:555.

12. Bemstein L, Qamar A, Mcpherson C, Zarich S, Rudolph R. Diagnosis of myocardial infarction: integration of serum markers and clinical descriptors using information theory. Yale J Biol Med. 1999;72:5-13.

13. Richmonds W. Determination of serum cholesterol. Clin Chem. 1973; $19: 1350$.

14. Fossati P, Prenciphe L. Determination of serum triglycerides. Clin Chem. 1982;28:207.

15. Rifai N, Wamrck R. Lipid, lipoproteins, apolipoproteins and other cardiovascular risk factors. In: Burtis CA, Ashwood ER, Bruns DE, editors. Tietz Textbook of Clinical Chemistry and Molecular Diagnosis. 4th ed. (Chap. 26). St. Louis, MO: Saunders; 2006:918-922.

16. Tanno K, Okamura T, Ohsawa M, et al. Comparison of low density lipoprotein cholesterol concentration measured by a direct homogeneous assay and by the Friedewald formula in a large community population. Clin Chim Acta. 2010;411:1774-1780.

17. Boder G, Porter S, Landt Y, Landerson J. Development of monoclonal antibodies for an assay of cardiac troponin 1 and preliminarily results in suspected cases of myocardial infarction. Clin Chem. 1992;38:2200-2214.

18. Yusuf S, Reddy S, Ounpuu S, Anand S. Global burden of cardiovascular diseases. Part I: general considerations, the epidemiologic transition, risk factors, and impact of urbanization. Circulation. 2001;104:2746-2753.

19. Liu X, Wang X, Shen Y, et al. The functional variant rs1048990 in PSMA6 is associated with susceptibility to myocardial infarction in a Chinese population. Atherosclerosis. 2009;206(1):199-203.

20. Guella I, Rimoldi V, Asselta R, et al. Association and functional analyses of MEF2A as a susceptibility gene for premature myocardial infarction and coronary artery disease. Circ Cardiovasc Genet. 2009;2(2): 165-172.

21. Schunkert H, Konig IR, Kathiresan S, et al. Large-scale association analysis identifies 13 new susceptibility loci for coronary artery disease. Nat Genet. 2011;43(4):333-338.

22. Coronary Artery Disease (C4D) Genetics Consortium. A genome-wide association study in Europeans and South Asians identifies five new loci for coronary artery disease. Nat Genet. 2011;43(4):338-344.

23. McCann CJ, Glover BM, Menown IB, et al. Prognostic value of a multimarker approach for patients presenting to hospital with acute chest pain. Am J Cardiol. 2009;103(1):22-28.
24. Miyazaki T, Shimada K, Mokuno H, Daida H. Adipocyte derived plasma protein, adiponectin, is associated with smoking status in patients with coronary artery disease. Heart. 2003;415:339-343.

25. American Heart Association. Risk Factors and Coronary Heart Disease. Update. Dallas, TX: American Heart Association; 2007.

26. Burazor IM, Burazor M. Troponin T in unstable angina pectoris. Med Biol. 2002;9:240-244.

27. Cannon C. Risk Factor Management”(RFM). In: Cannon C, Pinsky D, editors. Launching Medscape Cardiology's News Center. 3rd ed. (Chap. 15). Philadelphia, PA: WB Saunders; 2006:12-32.

28. Santos ES, Baltar VT, Pereira MP, Minuzzo L, Timerman A, Avezum A. Comparison between cardiac troponin I and CK-MB mass in acute coronary syndrome without ST elevation. Arg Bras Cardiol. 2011;96:179-187.

29. Inrig JK, Patel UD, Briley LP, et al. Mortality, kidney disease and cardiac procedures following acute coronary syndrome. Nephrol Dial Transplant. 2008;23(3):934-940.

30. Goraya TY, Leibson CL, Palumbo PJ, et al. Coronary atherosclerosis in diabetes mellitus: a population-based autopsy study. J Am Coll Cardiol. 2002;40(5):946-953.

31. Aso Y, Wakabayashi S, Yamamoto R, Matsutomo R, Takebayashi K, Inukai T. Metabolic syndrome accompanied by hypercholesterolemia is strongly associated with proinflammatory state and impairment of fibrinolysis in patients with type 2 diabetes: synergistic effects of plasminogen activator inhibitor-1 and thrombin-activatable fibrinolysis inhibitor. Diabetes Care. 2006;28(9):2211-2216.

32. Grundy S, Brewer H, Cleeman JI, Smith SC, Lenfant C. Definition of metabolic syndrome: report of the National Heart, Lung, and Blood Institute/American Heart Association conference on scientific issues related to definition. Circulation. 2004;109:433-438.

33. Devaraj S, Chan E, Jialal I. Direct demonstration of an anti inflammatory effect of simvastatin in subjects with the metabolic syndrome. J Clin Endocrinol Metab. 2006;91(11):4489-4496.

34. Pasaoglu H, Ofluoglu E, Ilhan MN, et al. The role of heart-type fatty acid-binding protein (HFABP) in acute myocardial infarction (AMI) compared to conventional cardiac biochemical markers. TurkJ Med Sci. 2007;37:61-67.

35. Loria V, Leo M, Biasillo G, Dato I, Biasucci LM. Biomarkers in acute coronary syndrome. Biomark Insights. 2008;5:453-468.

36. Gillis TE, Marshall CR, Tibbis GF. Functional and evolutionary relationships of troponin. Physiol Genomic. 2007;32:16-27.

37. Wang Y, Wang L, Liu X, et al. Genetic variants associated with myocardial infarction and the risk factors in Chinese population. PLoS One. 2004;9(1):e86332.

38. Chang W, Mo R, Zhang X, et al. Impact of PPAP 2B and TCF21 gene polymorphisms on risk of coronary heart disease in Chinese Han population. Int J Clin Exp Pathol. 2016;9:1963-1974.
Research Reports in Clinical Cardiology

\section{Publish your work in this journal}

Research Reports in Clinical Cardiology is an international, peerreviewed, open access journal publishing original research, reports, editorials, reviews and commentaries on all areas of cardiology in the clinic and laboratory. The manuscript management system is completely online and includes a very quick and fair peer-review system.

\section{Dovepress}

Visit http://www.dovepress.com/testimonials.php to read real quotes from published authors. 